\title{
Uncovering the Indirect Impact of Work Ethic on Engineering Students' Productivity through Positive and Negative Organizational Behaviors and Workaholism
}

\author{
Humayun Sattar *, Tasweer Hussain Syed (D, Afshan Naseem, Yasir Ahmad, Muhammad Zeeshan Mirza (D) \\ and Masood Raza
}

check for updates

Citation: Sattar, H.; Syed, T.H.; Naseem, A.; Ahmad, Y.; Mirza, M.Z.; Raza, M. Uncovering the Indirect Impact of Work Ethic on Engineering Students' Productivity through Positive and Negative Organizational Behaviors and Workaholism. Sustainability 2021, 13, 2922. https://doi.org/10.3390/su13052922

Academic Editor: José Alberto Molina

Received: 7 February 2021

Accepted: 2 March 2021

Published: 8 March 2021

Publisher's Note: MDPI stays neutral with regard to jurisdictional claims in published maps and institutional affiliations.

Copyright: (c) 2021 by the authors. Licensee MDPI, Basel, Switzerland. This article is an open access article distributed under the terms and conditions of the Creative Commons Attribution (CC BY) license (https:/ / creativecommons.org/licenses/by/ $4.0 /)$.
Department of Engineering Management, National University of Sciences and Technology, Islamabad 44000, Pakistan; tasweer@ceme.nust.edu.pk (T.H.S.); afshan.naseem@ceme.nust.edu.pk (A.N.); yasir.ahmad@ceme.nust.edu.pk (Y.A.); zeeshan.mirza@ceme.nust.edu.pk (M.Z.M.); masood.raza@ceme.nust.edu.pk (M.R.)

* Correspondence: humayun.sattar@ceme.nust.edu.pk

\begin{abstract}
The main objective of this study is to investigate the mediating effects of organizational citizenship behavior (OCB), destructive deviant behaviors (DDB), constructive deviant behaviors (CDB), and workaholism (WA) in the relationship between work ethic (WE) and the productivity of engineering students. Another objective is to present a comprehensive holistic model of relationships of these organizational behaviors (OB), attitudes, and work ethic with the productivity. Structure equation modeling (SEM) and Hayes' processes are used to analyze the hypothesized model. Data were randomly collected from 400 participants from the universities of Pakistan. The overall assessment of the model showed that WE indirectly effects productivity through mediating variables (OCB, $\mathrm{DDB}, \mathrm{CDB}, \mathrm{WA}$ ). One of the implications of this finding is that education practitioners/planners should promote work ethic (considered essential for sustainable management practices by contemporary researchers also) among engineering students. This ethic will be reflected in students' behaviors (enhanced positive behaviors/attitudes, i.e., $\mathrm{OCB}, \mathrm{CDB}$, and $\mathrm{WA}$, and reduced negative behaviors i.e., DDB) which will in turn improve their productivity. The originality of this research lies in it being the first to explore the indirect effect of Islamic work ethic (IWE) on individuals' productivity through OCB, DDB, CDB, and WA.
\end{abstract}

Keywords: organizational citizenship behavior (OCB); deviant behavior; destructive deviant behavior; constructive deviant behavior; work ethic; islamic work ethic; productivity; engineering students; developing countries

\section{Introduction}

Organizational behaviors (OB) and work ethic (WE) have been an area of great interest for researchers for a long time [1-5]. Contemporary researchers consider WE and organizational citizenship behaviors (OCB) essential for the strategy of sustainable management and for a sustainable world [6,7]. Researchers have found tangible effects of OBs and WE on the productivity of individuals and organizations [8]. Productivity of individuals and organizations can be enhanced through promotion of positive OBs, attitudes, and WE, and reduction of negative OBs [9-13]; however, study of the effects of OBs and WE among undergraduate (UG) engineering students has not been given due attention, as noted by scholars $[9,14]$. This research is an effort to enhance knowledge in this area to develop a comprehensive model of interrelations and effects of WE, organizational citizenship behaviors (OCB), destructive deviant behaviors (DDB), constructive deviant behaviors (CDB), and workaholism (WA) with productivity of engineering students. This research empirically explored the missing link between WE and productivity through behaviors and attitudes (OCB, DDB, CDB, and WA), proposing a model of these relationships and 
adding evidence to the body of knowledge from developing countries. The findings will be useful for academic planners/practitioners to enhance the academic productivity of the students.

Many positive and negative organizational behaviors like OCB, DDB, CDB, and work attitudes like WA and WE (like Islamic work ethic (IWE) in Islamic countries/societies) have been found to create positive and negative effects on the performance of organizations $[2,15,16]$ as a whole or on individuals' performance, working in those organizations $[17,18]$. However, a wholesome framework of studying the relationship of all these behaviors, ethics, and attitudes (WE, OCB, CDB, DDB, WA), which exist independently and distinctly among people and have effects on their productivity, is missing in contemporary literature. The present research empirically presents a comprehensive model of these relationships.

In a university context, researchers previously focused on studying OBs (OCB, DDB, CDB, WA) mostly among the faculty members and administrative staff [11]. Students were treated either as the customers or the product of engineering universities [19-23]. Bunce et al. [14] noted that as several governments like United Kingdom (UK) Government have officially declared students as consumers/customers, this management approach has a negative impact on the performance/productivity of students. Allison et al. [9] found through empirical study that UG business students exhibit OCB like coworkers/colleagues, and their performance is positively associated with the OCB. Despite the increasing importance of these behaviors and ethics in the universities, few empirical studies have examined their effects on engineering students' productivity [24]. We posit that as the engineering students, especially the UG students, spend a long duration of four to five years in engineering universities, they exhibit OBs (as studied previously by LeBlanc [9,23] like other members of the universities (faculty and administrative staff)), and it is an interesting area of research to explore the relationships of these positive and negative behaviors and ethics with students' productivity.

Similarly, the effects of IWE on productivity and performance have been studied by many academics [25-27] in Islamic societies; however, it was not clear how the IWE impacts the individuals' performance through manifested behaviors/attitudes. We posit that work ethic is an abstract phenomenon and its impact on productivity should be mediated by some discrete phenomena such as OBs and attitudes. The present paper presents our empirical research to formulate a model of impact of IWE on productivity through enhanced positive behaviors and reduced negative behaviors.

\section{Literature Review}

\subsection{OBs and Productivity}

Positive and negative OBs and their impacts on organizational and personal outcomes have been a subject of interest for researchers for many decades [2,10,16,28-31]. Out of positive behaviors, OCB is one behavior that gained a lot of attention from researchers and scholars. Its antecedents, relationships with other behaviors, attitudes, and effects on organizational outputs have been studied extensively. As noted by Koopman et al. [32], OCB is defined as "organizational behaviors that cannot be observed with the formal reward system or punishment." Podsakoff et al. [15] explain OCB as "the individual's discretionary behaviors which can't be recognized directly or through formal reward systems and that in collective encourage the effective functions to promote an organization." Several studies have shown OCB's positive effects on organizational success through improvements in productivity, teamwork, performance improvement, and constancy [15,24].

Deviant behavior is the departure of behavior from norms which are followed by the reference group. Deviant behavior can be divided into two opposite categories in the management literature [30]. One type of deviant behavior is mainly negative behavior, where employees harm or destroy the organization. The destructive employee deviance, in literature, includes unethical and undesirable employees' acts such as stealing or embezzling funds [33-37]. However, a second type of deviance from norms and rules may occur, 
which may be constructive for the organization and society and may be termed as constructive deviant behavior [38-40]. The positive deviant behavior may include functional disobedience, dissent, whistleblowing, and exercising voice [16]. Researchers have focused on various aspects such as DDB effects on personality, perceived justice, inequality, and harassment. However, DDB's effects on productivity is an area less explored and needs more study [41-44].

Galperin [16] is among the first scholars to conceptualize constructive forms of deviant behaviors, having both negative and positive views on its outcomes for the organizations. Constructive deviance has been defined as "discretionary behavior against significant organizational rules/norms to benefit an organization, its members, or both". Warren [28] found constructive deviance as an implicit benefit to the organization in the form of creativity, organizational citizenship behavior, or pro-social behavior, helping the organization.

Fox et al. [43] suggest that both OCB and counterwork behaviors (CWB) are independent i.e., both co-exist in the individuals. They also found a positive correlation between them, i.e., the employees engaging more in OCB also engage in CWB. The possible causes of co-existence of both behaviors are demanded OCB in an organization, social loafing, and enhanced stresses/pressures from supervisors. Dalal [44] suggested that employees engage in both OCB and CWB in the pursuit of positive affect and future satisfaction, as engaging in OCB or CWB can result in feelings of respite and fulfilment, and can satisfy needs for sensation. Our study is an effort to study the effects of these inter-related but independent behaviors together on productivity in a holistic model to understand their collective effects. We test the following hypotheses in our model:

Hypothesis 1 (H1). OCB will be positively related to productivity.

Hypothesis 2 (H2). DDB will be negatively related to productivity.

Hypothesis 3 (H3). CDB will be positively related to productivity.

\subsection{WA and Productivity}

Workaholism (WA) is considered an attitude due to which a person feels driven to work and cannot live without work. The term workaholism or work-holism was presented first by Oates [45], who defined workaholism as "a buzzword, an invented word, a semi-humorous word for addiction to work". Workaholics can be seen both positively and negatively in any organization. On the negative side, workaholics are addicts who cannot control themselves from work thus not giving attention to their social duties towards others and themselves; but on the positive side, they are mostly hardworking and devoted workers. He described this term as an irrepressible psychological desire to work continuously. Scholars indicate that workaholics constantly and permanently think about their work [46]. Snir and Zohar [47] define a workaholic as a person spending an extensive amount of time working and having continuous cognitive engagement to their jobs even during their leisure time. Many scholars have found that WA causes an increase in productivity of individuals [47]. The relationship of WA with positive and negative behaviors is ambiguous in the literature; some scholars consider WA a positive work attitude whereas others consider it a negative attitude. Hence, its relationship with behaviors and productivity also has two opposite views. Researchers have found that WA has no or a weak connection with performance and has a negative relationship with OCB $[45,48]$. However, Scottl et al. [12] found a positive relation between WA and performance and between WA and OCB. Based on this, we hypothesize that

Hypothesis 4 (H4). WA will be positively related to productivity. 


\subsection{WE and Productivity}

As noted by many researchers, the idea of WE in organizations was first presented by Weber in 1905 [49]. The Protestant work ethic (PWE) concept was based on the ideology of prudence, individuality, discipline, and hard work. Mostly, any group or organization's WE is derived from the religion or philosophy being practiced by that community. Ethics are moral judgments of any individual about right and wrong. Many researchers have found that mostly in Muslim countries, people follow Islamic work ethics (IWE) which have effects on their work outcomes, performances, and productivity [41,50-53]. We hypothesize in our study that

Hypothesis $\mathbf{5}$ (H5). IWE will be positively related to productivity.

\subsection{Indirect Effects of WE on Productivity through Mediators (OBs/WA)}

IWE has been studied as an influencing variable and moderator by Usman et al. [54], and they found this variable as a significant indicator of organizational performance and productivity. We posit that as ethics are the antecedents of behaviors, there is also a need to study the effects of IWE on productivity through positive and negative work behaviors and attitudes.

Work ethic, cultured and followed by the members of any society or organization, has significant effects on the behaviors and attitudes of the individuals themselves and affect their behaviors towards others (colleagues and the organization as a whole) $[6,55,56]$. In Islamic countries like Pakistan, where approximately $97 \%$ of the population is Muslim, the WE followed is IWE, which is a part of the individuals' education/grooming [53]. Many researchers have found that IWE has significant positive or negative relationships with individuals' positive and negative behaviors towards colleagues/organizations [57,58]. Scholars have found that behaviors and attitudes like unity, justice, the need for balance, and knowledge-seeking is promoted by IWE [58]. Naresh Kumar and Raduan Che Rose [51] institute from an empirical analysis that IWE positively impacts innovation capability. As innovation has been considered a product of constructive deviance in certain circumstances; hence, it can be argued that IWE will correlate to CDB positively and in turn will impact productivity. WA has been taken both as a positive and negative work attitude by researchers and scholars. However, the literature on IWE suggests that these ethics will help individuals to maintain a balance. Hence, IWE will positively impact productivity through WA.

Usman et al. [53] carried out a meta-analysis of studies on IWE. They summarized the effects of IWE found by researchers on behaviors, attitudes, job involvement, and organizational outcomes. The relationship between IWE and attitude towards change and innovation capability suggests that IWE may affect CDB and WA. They recommend research on its relations with negative attitudes/behaviors, and its moderating and mediating roles. They also point out the lack of logical argumentation in previous studies. Their study also strengthens the present study's basis to explore how IWE will affect any individuals' productivity. Abbasi et al. [52] found that IWE has a weak direct relation with performance; however, IWE impacts performance through organizational innovation and learning and they suggest further study of indirect impacts of WE on performance and productivity [59]. As the ethics are the beliefs and norms followed by a person or society and their practical manifestation to foster creativity has to come through the work behaviors and attitudes, it is imperative to study the indirect relationships of IWE with the productivity through mediating OBs. The following hypothesis was formed from preceding discussion/review:

Hypothesis 6 (H6). $O C B, D D B, C D B$, and WA will mediate the relationship of IWE with productivity. 


\subsection{Theoretical Framework}

Our theoretical framework for testing our hypotheses is shown in Figure 1:

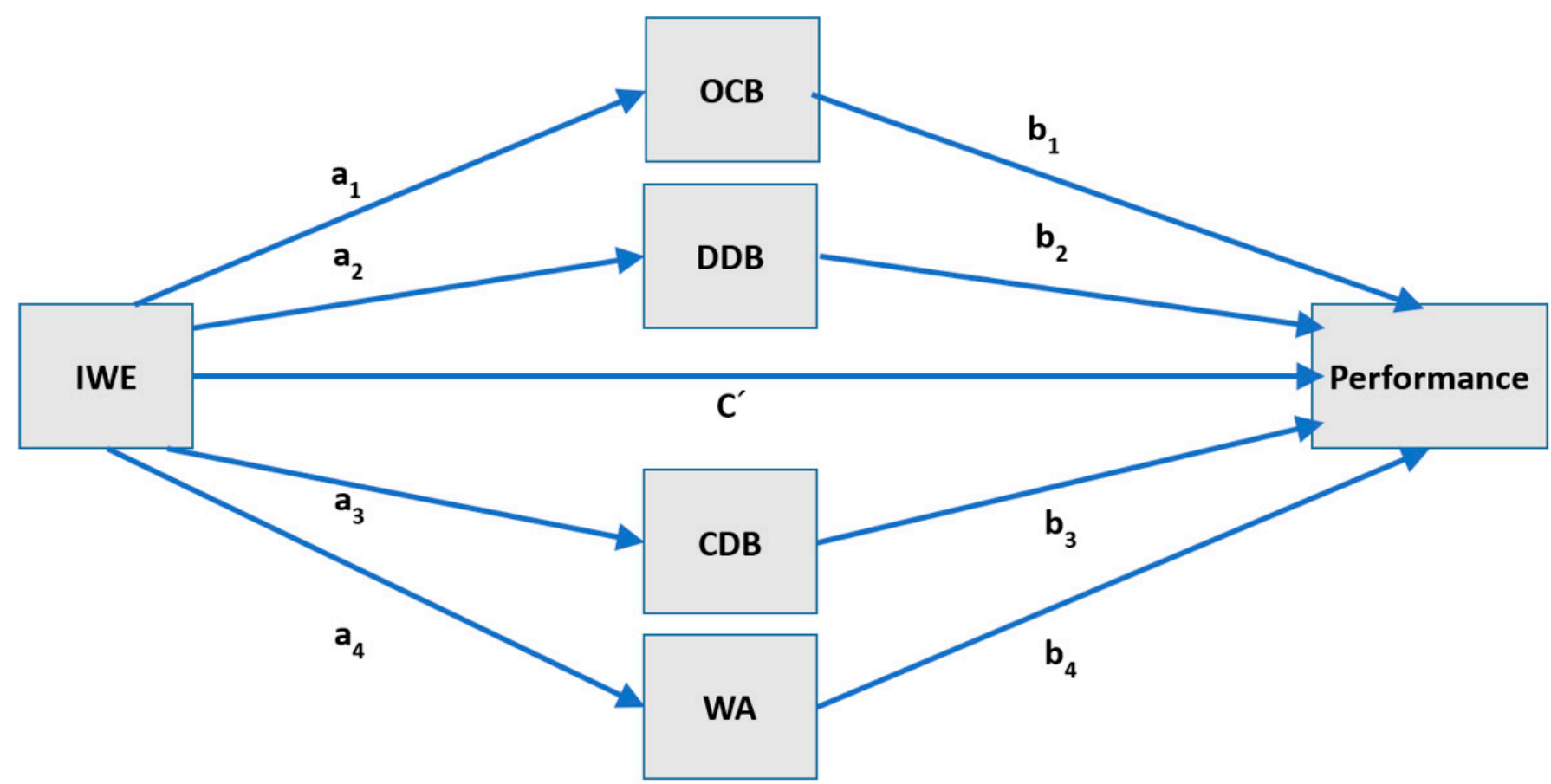

Figure 1. Effects of Islamic work ethic (IWE) on productivity through organizational citizenship behavior (OCB), constructive deviant behavior (CDB), destructive deviant behavior (DDB), and workaholism (WA). (Paths named as a, b, $c$ for mediation analysis.

\section{Method}

\subsection{Procedure}

A total of 600 UG students from three engineering universities were selected through random sampling. Out of 600 questionnaires, 423 were returned; 23 were discarded due to incomplete data and 400 questionnaires were used for data analysis after data cleansing/removal of outliers. The sample size is acceptable for $95 \%$ CI with $5 \%$ margin of error [60].

\subsection{Measures}

Instruments for $\mathrm{OCB}, \mathrm{DDB}, \mathrm{CDB}, \mathrm{WA}$, and IWE were adapted from well versant and extensively used measures used by researchers in this field (attached as Appendix A). The items' wordings were modified to suit the population (engineering students). A pilot study was conducted with 60 students and Cronbach Alpha was checked for all variables. As it was above 0.70 for all variables, the instrument was deemed fit for use. The details of instrument are as follows.

\section{3. $O C B$}

For measuring OCB, the 16-item scale by Podsakoff et al. [15], used by Khurram [11] and Pillai et al. [61], was adapted. Respondents answered on a five-point Likert scale ( 1 = strongly disagree; 5 = strongly agree). A sample item is "I am willing to take time out of my busy schedule to help and guide new students". Four items (item 8 to item 11) in this measure are reverse coded to add validity to the scale; for example, item 9 "I always find fault with what the university is doing". 


\subsection{Destructive Deviant Behavior (DDB)}

DDB was measured using 14 items adapted from Aquino et al. [37]. All items were rated on five-point Likert scales ( $1=$ strongly disagree; $5=$ strongly agree $)$.

\subsection{Constructive Deviant Behavior (CDB)}

The CDB measure was adapted from Galperin [42]. It is a 10-item instrument which has been used as a single construct. Respondents answered on a five-point Likert scale ( 1 = strongly disagree; 5 = strongly agree $)$.

\subsection{Workaholism (WA)}

For measurement of WA, the work addiction risk test (WART) was adapted from Robinson [35], which is a 25-item self-report inventory, assessing the respondents' work habits; each item is scored on a 5-point Likert scale. Scholars have found reliability and validity of this scale better than other scales to measure workaholism. The WART was selected being more appropriate to measure study holism. Respondents answered on a five-point Likert scale ( 1 = strongly disagree; 5 = strongly agree).

\subsection{Work Ethic (WE)/Islamic Work Ethic (IWE)}

The instrument used for the study was adapted from Ali [62]. This questionnaire on IWE comprised 17 items. Respondents answered on a five-point Likert scale $(1=$ strongly disagree; 5 = strongly agree).

\subsection{Productivity}

Students' academic productivity can be measured in different ways. Allison et al. [9], while studying the effects of OCB on undergraduate (UG) business students' performance, measured productivity as a product of semester grade point average (GPA) and semester load. However, Hysenbegasi et al. [63] have taken cumulative grade point average (CGPA) as an objective, observer-generated measure of academic productivity. Gaultney [64] has also used GPA as measure of academic performance. In Pakistan, 100\% of engineering universities/colleges use CGPA to measure the academic performance/productivity of engineering students; hence, in this study, CGPA was taken as a measure of academic productivity of engineering students. Furthermore, students from 3 rd semester to 8 th semester were considered a population of interest as their CGPA has been calculated well and they have been found to develop an affiliation with the institutions and start exhibiting OCB.

\section{Data Analysis}

SPSS and AMOS software were used for exploratory factor analysis (EFA), confirmatory factor analysis (CFA), and measuring reliability. Cronbach's alpha reliability coefficients were computed to test the internal consistency of the measurement items. We used a cutoff value of 0.70 [65] and all instruments showed internal consistency with Cronbach's alpha coefficients greater than 0.80. Average variance extracted (AVE), square root $\mathrm{AVE}$, and composite reliability $(\mathrm{CR})$ are also measured to confirm the consistency and reliability [66,67]. AVE values for OCB, DDB, CDB, WA, and IWE were 0.574, 0.590, 0.550, 0.573 and 0.638 , respectively. Square root $\mathrm{AVE}$ values for $\mathrm{OCB}, \mathrm{DDB}, \mathrm{CDB}, \mathrm{WA}$, and IWE were $0.757,0.768,0.741,0.756$, and 0.798 , respectively. CR values for OCB, DDB, CDB, WA, and IWE were $0.760,0.777,0.731,0.758$, and 0.829 respectively.

\section{Results and Discussion}

Before going to Hayes' process $[68,69]$ and studying the complete model with all corelated variables $(\mathrm{OCB}, \mathrm{DDB}, \mathrm{CDB}$ and $\mathrm{WA})$, as a first step, a linear regression was carried out using SPSS to find effects of independent variables (IVs), i.e., IWE, OCB, DDB, $\mathrm{CDB}$, and WA on the dependent variable (DV) i.e., CGPA (productivity). The independent effects of each variable on productivity are listed in Table 1 below. The $\mathrm{R}$ square and 
unstandardized beta values were noted as regression was carried out by putting only one independent variable at a time. The results showed that in the absence of other variables (OCB, DDB, CDB, WA), work ethic (IWE) had a significant effect on productivity, i.e., 17.1\% $\left(\mathrm{R}^{2}=0.171\right.$, beta $\left.=0.266, p=0.000\right)$. Similarly, OCB had an effect of $32.2 \%$, DDB an effect of $17.4 \%, \mathrm{CDB}$ an effect of $28.4 \%$, and WA an effect of $23.2 \%$. Our hypotheses H1, H2, H3, H4, and $\mathrm{H} 5$ are thus supported by the results.

Table 1. Regression results of single independent variables (IVs) (IWE, OCB, DDB, CDB, WA) on productivity.

\begin{tabular}{ccccccc}
\hline IV & DV & R Square & Beta Unstandardized & S.E. & $\boldsymbol{t}$-Value & $\boldsymbol{p}$-Value \\
\hline IWE & CGPA & 0.171 & 0.266 & 0.031 & 8.57 & 0.001 \\
OCB & CGPA & 0.322 & 0.501 & 0.039 & 13.17 & 0.001 \\
DDB & CGPA & 0.174 & -0.253 & 0.029 & -8.75 & 0.001 \\
CDB & CGPA & 0.284 & 0.344 & 0.028 & 12.27 & 0.001 \\
WA & CGPA & 0.232 & 0.340 & 032 & 10.15 & 0.001 \\
\hline
\end{tabular}

\subsection{Multiple Regression Results}

In a multiple regression model, to find the direct effects of OCB, DDB, CDB, WA, and IWE on productivity, standardized beta values were considered to remove any error caused by different scales. Results are shown in Table 2 below. The effect of IWE was not significant and coefficient value was negative $\left(R^{2}=-0.006, p=0.915\right)$, while other variables (OCB, DDB, CDB, and WA) showed significant effects on productivity.

Table 2. Multiple regression results (IWE, OCB, DDB, CDB, WA as covariate independent variables, productivity as dependent variable).

\begin{tabular}{cccccc}
\hline IV & DV & $\begin{array}{c}\text { Beta } \\
\text { (Unstandardized) }\end{array}$ & Standardized Beta & S.E. & $p$-Value \\
\hline IWE & CGPA & -0.004 & -0.006 & 0.039 & 0.915 \\
OCB & CGPA & 0.257 & 0.282 & 0.033 & 0.001 \\
DDB & CGPA & -0.34 & -0.54 & 0.038 & 0.378 \\
CDB & CGPA & 0.151 & 0.229 & 0.040 & 0.000 \\
WA & CGPA & 0.092 & 0.126 & 0.045 & 0.041 \\
\hline
\end{tabular}

\subsection{Discussion on Hypothesized Model}

As hypothesized in the present study and also found by previous studies, high work ethic and ethical values are one of the predictors of higher positive (productive) and lesser negative (counterproductive) behaviors [25,27]. In our hypothetical model (Figure 1), IWE is taken as predictor variable which causes increase in positive behaviors/attitudes (OCB, CDB, WA), and causes decrease in negative work behaviors (DDB), which in turn have effects on productivity. The model was tested using SPSS Hayes' process model 4 [68,69].

The hypothesized model discovered the very logical and understandable relationship of IWE with productivity. As is understandable, work ethic does not have direct effects on productivity, rather, the work ethic affects productivity by enhancing the positive behaviors required to increase productivity and reducing negative behaviors which were dropping the productivity. There are two commonly used methods of studying mediation; Barron and Kenny's method [70] and Preacher and Hayes' method [68,69,71]. This model was an example of perfect mediation while studied from both methods $[70,71]$. It is a great advancement in understanding and explaining the effects of IWE on productivity. The direct effects are shown in Table 3 below. The model clearly showed that IWE do affect productivity, however, it does not have a direct significant causal effect. In Figure 1, the direct path $C^{\prime}$ has values $\left(C^{\prime}=-0.004\right.$, S.E. $\left.=0.272, p=0.995\right)$; the path is not only nonsignificant but also the value is negative, in presence of mediating paths $\left(a_{1}, b_{1}\right),\left(a_{2}, b_{2}\right)$, $\left(a_{3}, b_{3}\right),\left(a_{4}, b_{4}\right)$ which are all significant, hence, as per Baron and Kenny's method, it is a 
perfect mediation. The results support our hypothesis (H6) that IWE affects productivity through indirect paths, i.e., behaviors and attitudes, i.e., OCB, CDB, DDB, and WA as mediating variables. The results also established that $\mathrm{OCB}, \mathrm{CDB}$, and WA are positive work behaviors/attitudes and enhance productivity, whereas DDB is a negative behavior which reduces productivity. However, those engineering students who are good in IWE will demonstrate low DDB and this will cause an enhanced productivity as DDB has negative relation with productivity.

Table 3. Direct effects of IVs/mediating variables (IWE, OCB, DDB, CDB, WA) on productivity in hypothesized model.

\begin{tabular}{cccccc}
\hline IV & DV & Path & Coefficient & S.E. & $p$-Value \\
\hline IWE & CGPA & $\mathrm{C}^{\prime}$ & -0.004 & 0.272 & 0.995 \\
IWE & OCB & $\mathrm{a}_{1}$ & 0.477 & 0.028 & 0.000 \\
IWE & DDB & $\mathrm{a}_{2}$ & -0.513 & 0.047 & 0.000 \\
IWE & CDB & $\mathrm{a}_{3}$ & 0.514 & 0.044 & 0.000 \\
IWE & WA & $\mathrm{a}_{4}$ & 0.576 & 0.036 & 0.000 \\
OCB & CGPA & $\mathrm{b}_{1}$ & 0.257 & 0.073 & 0.001 \\
DDB & CGPA & $\mathrm{b}_{2}$ & -0.034 & 0.038 & 0.037 \\
CDB & CGPA & $\mathrm{b}_{3}$ & 0.151 & 0.040 & 0.000 \\
WA & CGPA & $\mathrm{b}_{4}$ & 0.092 & 0.045 & 0.041 \\
\hline
\end{tabular}

\subsection{Mediation Analysis as per Preacher and Hayes' Method}

As per Preacher and Hayes' method, the mediation coefficients (AxB) are shown in Table 4 below. All coefficients are significant except DDB for which BootLLCI $=-0.025$ and BootULCI $=0.062$, hence it is concluded that according to Preacher and Hayes' method, the DDB does not significantly mediate the effect of IWE on productivity. Overall, total direct and indirect effect of IWE on productivity is 0.266 with S.E. $=0.031$ and $p$ value $=0.000$; which is a significant effect and supports the hypotheses that IWE has an indirect positive effect on productivity through $\mathrm{OCB}, \mathrm{DDB}, \mathrm{CDB}$, and WA. Alternatively, we can conclude that $\mathrm{OCB}, \mathrm{DDB}, \mathrm{CDB}$, and WA mediate the relationship of IWE and productivity. It is noted that the mediating relationship of DDB between IWE and productivity can be considered partial mediation based on bootstrapping confidence intervals, as it is not significant, whereas, as per Baron and Kenny's logic, this mediation is supported (as both paths $\mathrm{a}_{2}$ and $\mathrm{b}_{2}$ are significant).

Table 4. Mediation analysis using Hayes' process model 4 (bootstrap results).

\begin{tabular}{|c|c|c|c|c|c|c|c|c|}
\hline IV & & Med & & DV & $\begin{array}{l}\text { Effect } \\
\left(A^{*} B\right)\end{array}$ & S.E. & BootLLCI & BootULCI \\
\hline IWE & $\longrightarrow$ & OCB & $\longrightarrow$ & CGPA & 0.122 & 0.031 & 0.050 & 0.195 \\
\hline IWE & & DDB & $\longrightarrow$ & CGPA & 0.017 & 0.022 & -0.025 & 0.062 \\
\hline IWE & $\longrightarrow$ & $\mathrm{CDB}$ & $\longrightarrow$ & CGPA & 0.077 & 0.023 & 0.034 & 0.124 \\
\hline IWE & $\longrightarrow$ & WA & $\longrightarrow$ & CGPA & 0.053 & 0.026 & 0.002 & 0.103 \\
\hline
\end{tabular}

Our H1, i.e., that IWE will have positive effects on productivity was tested in the hypothesized model. Once tested independently in the absence of other variables $(\mathrm{OCB}$, $\mathrm{DDB}, \mathrm{CDB}, \mathrm{WA})$, IWE has a significant positive relationship with productivity $(\mathrm{b}=0.266$, $\mathrm{S} . \mathrm{E}=0.031, p=0.000$ ), but in the model with other variables, i.e., OCB, DDB, CDB and WA, the effect of IWE on productivity becomes negative and insignificant $(b=-0.004$, S.E $=0.272, p=0.995$ ). In the mediation model (Figure 1), with OCB, DDB, CDB, and WA as mediators, total direct and indirect effect of IWE on productivity is significant $(b=0.266$, $\mathrm{S} . \mathrm{E}=0.031, p=0.000$ ). This is a very interesting finding which explains that IWE's total effect on productivity is an indirect effect through increase in $\mathrm{OCB}, \mathrm{CDB}$, and $\mathrm{WA}$, and decrease in DDB. 
Our H6, i.e., "OCB, DDB, CDB, and WA will mediate the relationship of IWE and productivity" was also tested in hypothesized model. Bootstrap results showed that OCB, WA, and CDB are significant mediators between IWE and productivity. Bootstrap results of DDB's mediation were not significant in the model; however, its regression coefficients on both indirect paths $\mathrm{a}_{2}$ and $\mathrm{b}_{2}$ (Figure 1 and Table 3) were very much significant, i.e., both paths " $\mathrm{a}_{2}$ " from IWE to DDB and " $\mathrm{b}_{2}$ " from DDB to productivity were significant. Hence, the hypothesis is accepted.

The regression coefficients of IWE to DDB is -0.513 and of DDB to productivity is -0.034 , which means that higher IWE causes a reduction in DDB, and DDB has a negative relation with productivity, so reduction in DDB due to increase in IWE will cause an increase in productivity. The product of both paths is 0.017 , which means IWE has a positive effect on productivity through reduction in DDB, and this effect is small, i.e., $1.7 \%$ only. The major effects of IWE on productivity are through OCB, CDB, and WA i.e., 12.2\%, $7.7 \%$ and $5.3 \%$ respectively.

\section{Conclusions and Recommendations}

The present research's novel contribution is the explanation of the indirect effects of work ethic (IWE) on productivity through $\mathrm{OCB}, \mathrm{DDB}, \mathrm{CDB}$, and WA; engineering students exhibit/demonstrate work ethic (IWE in Pakistan having 97\% Muslim population) which has a positive effect on their productivity through positive/negative organizational work behaviors/attitudes. This finding is in line with contemporary scholars' findings including Allison et al. and Bunce et al. $[9,14,41,51]$. The results also suggested that studying the "independently existing but interrelated distinct work behaviors, attitudes, and ethics" in a wholesome model to understand their combined effects on productivity is a more logical, understandable, and explainable approach.

The model proposed by present research is a novel explanation of the effects of IWE on the productivity of individuals. Previous studies by Rice [50], Abbasi [52], Sattar and Syed [41], Ali [72], Usman et al. [53], and Rokhman [73] have found that IWE has effects on performance and productivity, as well as on various organizational/work behaviors and attitudes; however, how IWE factually produces effects on productivity was not clear. The present study has presented a concise model of how IWE affects OCB, DDB, CDB, and WA positively or negatively and ultimately causes an increase in productivity.

The study provides academic planners and policy makers with a knowledge with empirical evidence, to enhance engineering students' performance by promoting work ethic which will, in turn, enhance positive behaviors and discourage negative behaviors.

Knowledge from this research can be used in other fields/populations effectively for practical implications. The findings of the present study support the conclusions of previous researchers, i.e., Choi et al. [6], Alshihabat and Atan [7], and Aleksic' et al. [3], that members of organizations should be groomed on ethics and positive organizational behaviors and diminishing deviant behaviors for implementing sustainable human resource management strategies, maintaining a sustainable work environment, and for building a sustainable world. For enhancing these ethics and behaviors, experts have highlighted the importance of social capital [74], authentic [56], and participative leadership [55], co-created values [75], and organizational culture [3]. The present study concludes that by grooming individuals on WE will result in enhancing positive behaviors and diminishing destructive deviant behaviors which will result in increased productivity. It is worth mentioning that work ethic among students cannot be built by increasing the study hours or by including a course on "work ethic" in their curriculum. The work ethic reflects the culture of any society and can only be inculcated among students by developing an ethical culture in institutions. Integration of institutions and values for sustainable development is always recommended by scholars [76]. Only then can the summom bonum of WE be achieved by manifesting this elusive factor into a tangible outcome, i.e., enhanced productivity. Ethics and behaviors can contribute to building the change-maker universities [77] for a sustainable and better world. 


\section{Limitations of Present Study and Recommendations for Future Researchers}

The sample size and diversity of the sample were limited in the present research. Hence, there is a need for replications of similar studies in other developing and developed countries for convergence/strengthening of the empirical evidence of the relationships found in this paper. Research may be carried out in different population segments, with larger and multi-cultural samples. Adoption of research designs, including longitudinal studies and heterogeneous sampling, will be very useful. Researchers may replace IWE with other ethics, e.g., Protestant work ethic (PWE) or contemporary work ethic according to the population under study.

Author Contributions: Conceptualization, H.S. and T.H.S.; methodology, Y.A.; software, H.S.; validation, M.R., M.Z.M. and A.N.; formal analysis, H.S.; data curation, A.N.; writing-original draft preparation, H.S.; writing - review and editing, T.H.S. and M.R.; supervision, T.H.S. All authors have read and agreed to the published version of the manuscript.

Funding: The APC was partially funded by National University of Sciences and Technology (NUST), Pakistan

Institutional Review Board Statement: Not applicable.

Informed Consent Statement: Not applicable.

Data Availability Statement: Data can be provided on request; email: Humayun.sattar@ceme.nust. edu.pk.

Conflicts of Interest: The authors declare no conflict of interest.

\section{Appendix A. Measures for Variables of the Study}

Table A1. Organizational Citizenship Behaviors.

\begin{tabular}{|c|c|c|c|c|c|c|}
\hline $\mathbf{Q} \#$ & Question & Strongly Disagree & Disagree & Neutral & Agree & Strongly Agree \\
\hline 1 & $\begin{array}{l}\text { I willingly give out my time to help others out who } \\
\text { have work or study related problems. }\end{array}$ & 1 & 2 & 3 & 4 & 5 \\
\hline 2 & $\begin{array}{l}\text { I am willing to take time out of my busy schedule } \\
\text { to help and guide new students. }\end{array}$ & 1 & 2 & 3 & 4 & 5 \\
\hline 3 & $\begin{array}{l}\text { I usually "touch base" with others (communicate) } \\
\text { before initiating actions that might affect them. }\end{array}$ & 1 & 2 & 3 & 4 & 5 \\
\hline 4 & $\begin{array}{l}\text { I take steps to try to prevent problems with other } \\
\text { students / personnel in the university. }\end{array}$ & 1 & 2 & 3 & 4 & 5 \\
\hline 5 & $\begin{array}{l}\text { I attend functions that are not required } \\
\text { (compulsory) but help the university's image. }\end{array}$ & 1 & 2 & 3 & 4 & 5 \\
\hline 6 & $\begin{array}{l}\text { I attend training/information sessions that I am } \\
\text { encouraged to, but not required to attend. }\end{array}$ & 1 & 2 & 3 & 4 & 5 \\
\hline 7 & $\begin{array}{l}\text { I attend and actively participate in university } \\
\text { meetings. }\end{array}$ & 1 & 2 & 3 & 4 & 5 \\
\hline 8 & $\begin{array}{l}\text { I consume a lot of time complaining about trivial } \\
\text { matters. }\end{array}$ & 1 & 2 & 3 & 4 & 5 \\
\hline 9 & $\begin{array}{l}\text { I always find fault with what the university is } \\
\text { doing. }\end{array}$ & 1 & 2 & 3 & 4 & 5 \\
\hline 10 & $\begin{array}{l}\text { I tend to make "mountains out of molehills" or } \\
\text { make problems worse than they are. }\end{array}$ & 1 & 2 & 3 & 4 & 5 \\
\hline 11 & $\begin{array}{l}\text { I usually focus on what is wrong with my situation } \\
\text { rather than the positive side of it. }\end{array}$ & 1 & 2 & 3 & 4 & 5 \\
\hline 12 & I rarely take long breaks. & 1 & 2 & 3 & 4 & 5 \\
\hline 13 & $\begin{array}{l}\text { I do not take unnecessary time off my } \\
\text { studies/work. }\end{array}$ & 1 & 2 & 3 & 4 & 5 \\
\hline 14 & I do not take extra breaks. & 1 & 2 & 3 & 4 & 5 \\
\hline 15 & My attendance at classes/work is above the norm. & 1 & 2 & 3 & 4 & 5 \\
\hline 16 & $\begin{array}{l}\text { I obey university rules and regulations even when } \\
\text { no one is watching. }\end{array}$ & 1 & 2 & 3 & 4 & 5 \\
\hline
\end{tabular}


Table A2. Destructive Deviant Behaviors.

\begin{tabular}{|c|c|c|c|c|c|c|}
\hline Q\# & Question & Strongly Disagree & Disagree & Neutral & Agree & Strongly Agree \\
\hline 1 & $\begin{array}{l}\text { Made an ethnic, racial, or religious slur against a } \\
\text { classmate. }\end{array}$ & 1 & 2 & 3 & 4 & 5 \\
\hline 2 & Swore at a classmate (call down upon/curse). & 1 & 2 & 3 & 4 & 5 \\
\hline 3 & Refused to talk to a classmate. & 1 & 2 & 3 & 4 & 5 \\
\hline 4 & Gossiped about my lecturer. & 1 & 2 & 3 & 4 & 5 \\
\hline 5 & $\begin{array}{l}\text { Made an obscene comment or gesture at a } \\
\text { classmate. }\end{array}$ & 1 & 2 & 3 & 4 & 5 \\
\hline 6 & $\begin{array}{l}\text { classmate. } \\
\text { Teased a classmate in front of other students. }\end{array}$ & 1 & 2 & 3 & 4 & 5 \\
\hline 7 & Intentionally arrived late to class. & 1 & 2 & 3 & 4 & 5 \\
\hline 8 & Called in sick when I was not really ill. & 1 & 2 & 3 & 4 & 5 \\
\hline 9 & $\begin{array}{l}\text { Took undeserved breaks to avoid work/studies } \\
\text { during class. }\end{array}$ & 1 & 2 & 3 & 4 & 5 \\
\hline 10 & Made unauthorized use of university property. & 1 & 2 & 3 & 4 & 5 \\
\hline 11 & Left class early without permission. & 1 & 2 & 3 & 4 & 5 \\
\hline 12 & $\begin{array}{l}\text { Lied about the number of hours I worked on } \\
\text { assignments. }\end{array}$ & 1 & 2 & 3 & 4 & 5 \\
\hline 13 & $\begin{array}{l}\text { Worked on a personal matter during the group } \\
\text { project instead of doing for my group. }\end{array}$ & 1 & 2 & 3 & 4 & 5 \\
\hline 14 & Purposely ignored my lecturer's instruction. & 1 & 2 & 3 & 4 & 5 \\
\hline
\end{tabular}

Table A3. Constructive deviant behaviors.

\begin{tabular}{|c|c|c|c|c|c|c|}
\hline Q \# & Question & Strongly Disagree & Disagree & Neutral & Agree & Strongly Agree \\
\hline 1 & $\begin{array}{l}\text { Sought to bend or break the rules in order to } \\
\text { perform my job/assignment/project/research } \\
\text { work. }\end{array}$ & 1 & 2 & 3 & 4 & 5 \\
\hline 2 & $\begin{array}{l}\text { Violated university procedures in order to solve a } \\
\text { problem/for betterment of university. }\end{array}$ & 1 & 2 & 3 & 4 & 5 \\
\hline 3 & $\begin{array}{l}\text { Departed from university procedures to solve a } \\
\text { problem related to other students / faculty or a } \\
\text { customer of university, e.g., some Industrial } \\
\text { organization. }\end{array}$ & 1 & 2 & 3 & 4 & 5 \\
\hline 4 & $\begin{array}{l}\text { Bent a rule to satisfy needs of other } \\
\text { students / faculty or a customer of university, e.g., } \\
\text { some industrial organization. }\end{array}$ & 1 & 2 & 3 & 4 & 5 \\
\hline 5 & $\begin{array}{l}\text { Departed from dysfunctional university policies or } \\
\text { procedures to solve a study/research-related } \\
\text { problem. }\end{array}$ & 1 & 2 & 3 & 4 & 5 \\
\hline 6 & $\begin{array}{l}\text { Reported a wrongdoing to co-workers/fellow } \\
\text { students to bring about a positive organizational } \\
\text { change. }\end{array}$ & 1 & 2 & 3 & 4 & 5 \\
\hline 7 & $\begin{array}{l}\text { Did not follow the orders of my supervisor/faculty } \\
\text { in order to improve work } \\
\text { procedures/studies/research. }\end{array}$ & 1 & 2 & 3 & 4 & 5 \\
\hline 8 & $\begin{array}{l}\text { Disagreed with others in my work/research } \\
\text { group/class in order to improve the current } \\
\text { work/class/lab procedures. }\end{array}$ & 1 & 2 & 3 & 4 & 5 \\
\hline 9 & $\begin{array}{l}\text { Disobeyed the teacher's/supervisor's instructions } \\
\text { to perform more efficiently. }\end{array}$ & 1 & 2 & 3 & 4 & 5 \\
\hline 10 & $\begin{array}{l}\text { Reported a wrongdoing to another person in my } \\
\text { university/university management to bring about } \\
\text { a positive organizational change. }\end{array}$ & 1 & 2 & 3 & 4 & 5 \\
\hline
\end{tabular}


Table A4. Workaholism/addiction to work/studies.

\begin{tabular}{|c|c|c|c|c|c|c|}
\hline Q \# & Question & Strongly Disagree & Disagree & Neutral & Agree & Strongly Agree \\
\hline 1 & $\begin{array}{l}\text { I prefer to do most things myself rather than ask } \\
\text { for help. }\end{array}$ & 1 & 2 & 3 & 4 & 5 \\
\hline 2 & $\begin{array}{l}\text { I get very impatient when I have to wait for } \\
\text { someone else or when something takes too long, } \\
\text { such as long, slow-moving lines. }\end{array}$ & 1 & 2 & 3 & 4 & 5 \\
\hline 3 & I seem to be in a hurry and racing against the clock. & 1 & 2 & 3 & 4 & 5 \\
\hline 4 & $\begin{array}{l}\text { I get irritated when I am interrupted while I am in } \\
\text { the middle of something. }\end{array}$ & 1 & 2 & 3 & 4 & 5 \\
\hline 5 & I stay busy and keep many irons in the fire. & 1 & 2 & 3 & 4 & 5 \\
\hline 6 & $\begin{array}{l}\text { I find myself doing two or three things at one time } \\
\text { such as eating lunch and writing a memo/doing } \\
\text { my assignments, while talking on the telephone. }\end{array}$ & 1 & 2 & 3 & 4 & 5 \\
\hline 7 & $\begin{array}{l}\text { I overly commit myself by biting off more than I } \\
\text { can chew. }\end{array}$ & 1 & 2 & 3 & 4 & 5 \\
\hline 8 & I feel guilty when I am not working on something. & 1 & 2 & 3 & 4 & 5 \\
\hline 9 & $\begin{array}{l}\text { It is important that I see the concrete results of } \\
\text { what I do. }\end{array}$ & 1 & 2 & 3 & 4 & 5 \\
\hline 10 & $\begin{array}{l}\text { I am more interested in the final result of my work } \\
\text { than in the process. }\end{array}$ & 1 & 2 & 3 & 4 & 5 \\
\hline 11 & $\begin{array}{l}\text { Things just never seem to move fast enough or get } \\
\text { done fast enough for me. }\end{array}$ & 1 & 2 & 3 & 4 & 5 \\
\hline 12 & $\begin{array}{l}\text { I lose my temper when things don't go my way or } \\
\text { work out to suit me. }\end{array}$ & 1 & 2 & 3 & 4 & 5 \\
\hline 13 & $\begin{array}{l}\text { I ask the same question over again, without } \\
\text { realizing it, after I've already been given the } \\
\text { answer once. }\end{array}$ & 1 & 2 & 3 & 4 & 5 \\
\hline 14 & $\begin{array}{l}\text { I spend a lot of time mentally planning and } \\
\text { thinking about future events while tuning out the } \\
\text { here and now. }\end{array}$ & 1 & 2 & 3 & 4 & 5 \\
\hline 15 & $\begin{array}{l}\text { I find myself still working after my co-workers } \\
\text { have called it quits. }\end{array}$ & 1 & 2 & 3 & 4 & 5 \\
\hline 16 & $\begin{array}{l}\text { I get angry when people don't meet my standards } \\
\text { of perfection. }\end{array}$ & 1 & 2 & 3 & 4 & 5 \\
\hline 17 & $\begin{array}{l}\text { I get upset when I am in situations where I cannot } \\
\text { be in control. }\end{array}$ & 1 & 2 & 3 & 4 & 5 \\
\hline 18 & $\begin{array}{l}\text { I tend to put myself under pressure with } \\
\text { self-imposed deadlines when I work. }\end{array}$ & 1 & 2 & 3 & 4 & 5 \\
\hline 19 & It is hard for me to relax when I'm not working. & 1 & 2 & 3 & 4 & 5 \\
\hline 20 & $\begin{array}{l}\text { I spend more time working than on socializing } \\
\text { with friends, on hobbies, or on leisure activities. }\end{array}$ & 1 & 2 & 3 & 4 & 5 \\
\hline 21 & $\begin{array}{l}\text { I dive into projects to get a head start before all the } \\
\text { phases have been finalized. }\end{array}$ & 1 & 2 & 3 & 4 & 5 \\
\hline 22 & $\begin{array}{l}\text { I get upset with myself for making even the } \\
\text { smallest mistake. }\end{array}$ & 1 & 2 & 3 & 4 & 5 \\
\hline 23 & $\begin{array}{l}\text { I put more thought, time, and energy into my work } \\
\text { than I do into my relationships, with my spouse (or } \\
\text { lover) and family. }\end{array}$ & 1 & 2 & 3 & 4 & 5 \\
\hline 24 & $\begin{array}{l}\text { I forget, ignore, or minimize important family } \\
\text { celebrations such as birthdays, reunions, } \\
\text { anniversaries, or holidays. }\end{array}$ & 1 & 2 & 3 & 4 & 5 \\
\hline 25 & $\begin{array}{l}\text { I make important decisions before I have all the } \\
\text { facts and have a chance to think them through } \\
\text { thoroughly. }\end{array}$ & 1 & 2 & 3 & 4 & 5 \\
\hline
\end{tabular}


Table A5. Islamic work ethics.

\begin{tabular}{|c|c|c|c|c|c|c|}
\hline Q \# & Question & Strongly Disagree & Disagree & Neutral & Agree & Strongly Agree \\
\hline 1 & I believe that laziness is a vice (weakness). & 1 & 2 & 3 & 4 & 5 \\
\hline 2 & I believe that dedication to work is a virtue. & 1 & 2 & 3 & 4 & 5 \\
\hline 3 & Good work benefits both one's self and others. & 1 & 2 & 3 & 4 & 5 \\
\hline 4 & $\begin{array}{l}\text { Justice and generosity in the workplace are } \\
\text { necessary conditions for society's welfare. }\end{array}$ & 1 & 2 & 3 & 4 & 5 \\
\hline 5 & $\begin{array}{l}\text { Producing more than enough to meet one's needs } \\
\text { contributes to the prosperity of society as a } \\
\text { whole. }\end{array}$ & 1 & 2 & 3 & 4 & 5 \\
\hline 6 & $\begin{array}{l}\text { One should carry work out to the best of one's } \\
\text { ability. }\end{array}$ & 1 & 2 & 3 & 4 & 5 \\
\hline 7 & $\begin{array}{l}\text { Work is not an end in itself but a means to foster } \\
\text { personal growth and social relations. }\end{array}$ & 1 & 2 & 3 & 4 & 5 \\
\hline 8 & Life has no meaning without work. & 1 & 2 & 3 & 4 & 5 \\
\hline 9 & More leisure time is good for society. & 1 & 2 & 3 & 4 & 5 \\
\hline 10 & $\begin{array}{l}\text { Human relations should be emphasized and } \\
\text { encouraged. }\end{array}$ & 1 & 2 & 3 & 4 & 5 \\
\hline 11 & Work enables man to control nature. & 1 & 2 & 3 & 4 & 5 \\
\hline 12 & $\begin{array}{l}\text { Creative work is a source of happiness and } \\
\text { accomplishment. }\end{array}$ & 1 & 2 & 3 & 4 & 5 \\
\hline 13 & $\begin{array}{l}\text { Any person who works hard is more likely to get } \\
\text { ahead in life. }\end{array}$ & 1 & 2 & 3 & 4 & 5 \\
\hline 14 & Work gives one the chance to be independent. & 1 & 2 & 3 & 4 & 5 \\
\hline 15 & $\begin{array}{l}\text { A successful person is the one who meets } \\
\text { deadlines at work. }\end{array}$ & 1 & 2 & 3 & 4 & 5 \\
\hline 16 & $\begin{array}{l}\text { One should constantly work hard to meet } \\
\text { responsibilities. }\end{array}$ & 1 & 2 & 3 & 4 & 5 \\
\hline 17 & $\begin{array}{l}\text { The value of work is delivered from the } \\
\text { accompanying intention rather than its result. }\end{array}$ & 1 & 2 & 3 & 4 & 5 \\
\hline
\end{tabular}

\section{References}

1. Andre, R. Organizational Behavior: An Introduction to Your Life in Organizations; Pearson Education: New Delhi, India, 2008 ; p. 616.

2. Wang, T.; He, Q.; Lu, Y.; Yang, D. How Does Organizational Citizenship Behavior (OCB) Affect the performance of megaprojects? Insights from a System Dynamic Simulation. Sustainability 2018, 10, 1708. [CrossRef]

3. Aleksić, A.; Načinović Braje, I.; Rašić Jelavić, S. Creating Sustainable Work Environments by Developing Cultures that Diminish Deviance. Sustainability 2019, 11, 7031. [CrossRef]

4. Stoffers, J.; van der Heijden, B.; Schrijver, I. Towards a Sustainable Model of Innovative Work Behaviors' Enhancement: The Mediating Role of Employability. Sustainability 2020, 12, 159. [CrossRef]

5. Arslan, M. The Work Ethic Values of Protestant British, Catholic Irish and Muslim Turkish Managers. J. Bus. Ethics 2001, 31, 321-339. [CrossRef]

6. Choi, J.; Sohn, Y.W.; Lee, S. The Effect of Corporate Social Responsibility on Employees' Organizational Citizenship Behavior: A Moderated Mediation Model of Grit and Meaning Orientation. Sustainability 2020, 12, 5411. [CrossRef]

7. Alshihabat, K.; Atan, T. The Mediating Effect of Organizational Citizenship Behavior in the Relationship between Transformational Leadership and Corporate Social Responsibility Practices: Middle Eastern Example/Jordan. Sustainability 2020, 12, 4248. [CrossRef]

8. Ocampo, L.; Acedillo, V.; Bacunador, A.M.; Balo, C.C.; Lagdameo, Y.J.; Tupa, N.S. A historical review of the development of organizational citizenship behavior (OCB) and its implications for the twenty-first century. Pers. Rev. 2018, 47, 821-862. [CrossRef]

9. Allison, B.J.; Voss, R.S.; Dryer, S. Student classroom and career success: The role of organizational citizenship behavior. J. Educ. Bus. 2001, 762, 82-88. [CrossRef]

10. Cohen, A.; Tura, B.E.; Vashdi, D.R. The relationship between social exchange variables, OCB, and performance: What happens when you consider group characteristics? Pers. Rev. 2012, 41, 705-731. [CrossRef]

11. Khurram, S. Development of Model of Organization Citizenship Behavior (OCB): A Comparative study of University Teachers from a Development and a Developed Country. Ph.D. Thesis, VIT University, Vellore, India, 2020.

12. Scottl, K.S.; Moore, K.S.; Miceli, M.P. An Exploration of the Meaning and Consequences of Workaholism. Hum. Relat. 1997, 50, 287-314. [CrossRef] 
13. Smith, C.A.; Organ, D.W.; Near, J.P. Organizational citizenship behavior: Its nature and antecedents. J. Appl. Psychol. 1983, 68, 653-663. [CrossRef]

14. Bunce, L.; Baird, A.; Jones, S.E. The student-as-consumer approach in higher education and its effects on academic performance. Stud. High. Educ. 2017, 42, 1958-1978. [CrossRef]

15. Podsakoff, P.M.; MacKenzie, S.B.; Paine, J.B.; Bachrach, D.G. Organizational citizenship behaviors: A critical review of the theoretical and empirical literature and suggestions for future research. J. Manag. 2000, 26, 513-563. [CrossRef]

16. Galperin, B.L.; Burke, R.J. Uncovering the relationship between workaholism and workplace destructive and constructive deviance: An exploratory study. Int. J. Hum. Resour. Manag. 2006, 17, 331-347. [CrossRef]

17. Berry, C.M.; Ones, D.S.; Sackett, P.R. Interpersonal deviance, organizational deviance, and their common correlates: A review and meta-analysis. J. Appl. Psychol. 2007, 92, 410. [CrossRef]

18. Chalcraft, D.; Hilton, T.; Hughes, T. Customer, collaborator or co-creator? What is the role of the student in a changing higher education servicescape? J. Mark. High. Educ. 2015, 25, 1-4. [CrossRef]

19. George, D. Market overreach: The student as customer. J. Socio. Econ. 2007, 36, 965-977. [CrossRef]

20. Mark, E. Student satisfaction and the customer focus in higher education. J. High. Educ. Policy. Manag. 2013, 35, 2-10. [CrossRef]

21. Browne, B.A.; Kaldenberg, D.O.; Browne, W.G.; Brown, D.J. Student as Customer: Factors Affecting Satisfaction and Assessments of Institutional Quality. J. Mark. High. Educ. 1998, 8, 1-14. [CrossRef]

22. Groccia, J.E. The Student as Customer versus the Student as Learner. Campus 1997, 2, 31-32. [CrossRef]

23. Yam, K.C.; Klotz, A.; He, W.; Reynolds, S.J. Turning Good Soldiers into Bad Apples: Examining when and why Citizenship Behavior Leads to Deviance; Academy of Management Proceedings: New York, NY, USA, 2014; p. 10439.

24. LeBlanc, C.J. Characteristics Shaping College Student Organizational Citizenship Behavior. Am. J. Bus. Educ. 2014, 7, 99-108. [CrossRef]

25. Bahareh, A.N. Analyzing the Relationships between Work Ethics, Productivity and Creativity. Ethics Sci. Technol. 2018, 13, 79-84.

26. Rosyada, D.; Mufraini, M.A.; Suherlan, A.; Harmadi, H.; Supriyono, S. Promoting Islamic Values to Encourage Labour Performance and Productivity: Evidence from Some Indonesian Industries. Int. J. Bus. Soc. 2018, 19, 591-604.

27. Sapada, A.F.A.; Modding, H.B.; Gani, A.; Nujum, S. The effect of organizational culture and work ethics on job satisfaction and employees performance. INA-Rxiv 2018, 6, 28-36.

28. Warren, D.E. Constructive and Destructive Deviance in Organizations. Acad. Manag. Rev. 2003, 28, 622-632. [CrossRef]

29. Khan, A.; Bibi, S.; Lyu, J.; Garavelli, A.C.; Pontrandolfo, P.; de Sanchez, P.M.A. Uncovering Innovativeness in Spanish Tourism Firms: The Role of Transformational Leadership, OCB, Firm Size, and Age. Sustainability 2020, 12, 3989. [CrossRef]

30. Islam, T.; Khan Sur, R.; Ahmad, U.N.U.; Ahmed, I. Exploring the Relationship between POS, OLC, Job Satisfaction and OCB. Procedia Soc. Behav. Sci. 2014, 114, 164-169. [CrossRef]

31. Tambe, S.; Shanker, D.M. A Study of Organizational Citizenship Behaviour and Job Stress in a Manufacturing Company in Mumbai. Available online: http:/ / dspace.vnbrims.org:13000/xmlui/handle/123456789/3621 (accessed on 15 April 2015).

32. Koopman, J.; Lanaj, K.; Scott, B.A. Integrating the bright and dark sides of OCB: A daily investigation of the benefits and costs of helping others. Acad. Manag. J. 2016, 59, 414-435. [CrossRef]

33. Bennett, R.J.; Robinson, S.L. Development of a measure of workplace deviance. J. Appl. Psychol. 2000, 85, 349. [CrossRef]

34. Bennett, R.J.; Robinson, S.L. The past, present, and future of workplace deviance research. In Organizational Behavior: The State of the Science, 2nd ed.; Mahwah, N.J., Ed.; Lawrence Erlbaum Associates Publishers: Mahwah, NJ, USA, $2003 ;$ pp. $247-281$.

35. Robinson, S.L.; Bennett, R.J. A typology of deviant workplace behaviors: A multidimensional scaling study. Acad. Manag. J. 1995, $38,555-572$.

36. Giacalone, R.A.; Knouse, S.B. Justifying wrongful employee behavior: The role of personality in organizational sabotage. J. Bus. Ethics 1990, 9, 55-61. [CrossRef]

37. Aquino, K.; Lewis, M.U.; Bradfield, M. Justice constructs, negative affectivity, and employee deviance: A proposed model and empirical test. J. Organ. Behav. 1999, 20, 1073-1091. [CrossRef]

38. Fox, S.; Spector, P.E.; Miles, D. Counterproductive Work Behavior (CWB) in Response to Job Stressors and Organizational Justice: Some Mediator and Moderator Tests for Autonomy and Emotions. J. Vocat. Behav. 2001, 59, 291-309. [CrossRef]

39. Ambrose, M.L.; Seabright, M.A.; Schminke, M. Sabotage in the workplace: The role of organizational injustice. Organ. Behav. Hum. Decis. Process. 2002, 89, 947-965. [CrossRef]

40. Einarsen, S.; Skogstad, A. Bullying at work: Epidemiological findings in public and private organizations. Eur. J. Work. Organ. Psychol. 1996, 5, 185-201. [CrossRef]

41. Sattar, H.; Syed, T.H. Exploring Relationships of Positive and Negative Organizational Behaviors (OB) with the Productivity of Engineering Students. Glob. Soc. Sci. Rev. 2020, 14, 269-282.

42. Galperin, B.L. Exploring the Nomological Network of Workplace Deviance: Developing and Validating a Measure of Constructive Deviance. J. Appl. Soc. Psychol. 2012, 42, 2988-3025. [CrossRef]

43. Fox, S.; Spector, P.E.; Goh, A.; Bruursema, K.; Kessler, S.R. The deviant citizen: Measuring potential positive relations between counterproductive work behaviour and organizational citizenship behaviour: The deviant citizen. J. Occup. Organ. Psychol. 2012, 85, 199-220. [CrossRef]

44. Dalal, R.S. A meta-analysis of the relationship between organizational citizenship behavior and counterproductive work behavior. J. Appl. Psychol. 2005, 90, 1241. [CrossRef] 
45. Oates, W.E. Confessions of a Workaholic: The Facts about Work Addiction; World Publishing Company: New York, NY, USA, 1971.

46. Alessandri, G.; De Longis, E.; Perinelli, E.; Balducci, C.; Borgogni, L. The costs of working too hard: Relationships between workaholism, job demands, and prosocial organizational citizenship behavior. J. Pers. Psychol. 2020, 19, 24-32. [CrossRef]

47. Snir, R.; Zohar, D. Workaholism as Discretionary Time Investment at Work: An Experience-Sampling Study. Appl. Psychol. 2008, 57, 109-127. [CrossRef]

48. Aziz, S.; Pittman, C.; Wuensch, K. Workaholism and organizational citizenship behaviors: Exploring gender role beliefs. Int. J. Workplace Health Manag. 2020, 13, 413-425. [CrossRef]

49. Cokley, K.; Komarraju, M.; Pickett, R.; Shen, F.; Patel, N.; Belur, V. Ethnic Differences in Endorsement of the Protestant Work Ethic: The Role of Ethnic Identity and Perceptions of Social Class. J. Soc. Psychol. 2007, 147, 75-89. [CrossRef]

50. Rice, G. Islamic Ethics and the Implications for Business. J. Bus. Ethics 1999, 18, 345-358. [CrossRef]

51. Kumar, N.; Rose, R.C. Examining the link between Islamic work ethic and innovation capability. J. Manag. Dev. 2010, $29,79-93$. [CrossRef]

52. Abbasi, A.S.; Mir, G.M.; Hussain, M. Islamic Work Ethics: How It Affects Organizational Learning, Innovation and Performance; Rochester: New York, NY, USA, 2012.

53. Usman, M.; Shahzad, K.; Khan, K. Islamic Work Ethics (IWE): A Review of Litrature and Directions for Future Research. J. Islam. Bus. Manag. 2015, 219, 1-28. [CrossRef]

54. Jeong, Y.; Kim, E.; Kim, M.; Zhang, J.J. Exploring Relationships among Organizational Culture, Empowerment, and Organizational Citizenship Behavior in the South Korean Professional Sport Industry. Sustainability 2019, 11, 5412. [CrossRef]

55. Hayat Bhatti, M.; Ju, Y.; Akram, U.; Hasnat Bhatti, M.; Akram, Z.; Bilal, M. Impact of Participative Leadership on Organizational Citizenship Behavior: Mediating Role of Trust and Moderating Role of Continuance Commitment: Evidence from the Pakistan Hotel Industry. Sustainability 2019, 11, 1170. [CrossRef]

56. Iqbal, S.; Farid, T.; Ma, J.; Khattak, A.; Nurunnabi, M. The Impact of Authentic Leadership on Organizational Citizenship Behaviours and the Mediating Role of Corporate Social Responsibility in the Banking Sector of Pakistan. Sustainability 2018, 10, 2170. [CrossRef]

57. Sattar, H.; Syed, T.H.; Naseem, A. Abstract ID: AIMC-2020-EBM-529 Do Students in Engineering Universities behave like Employees/Co-workers? Exploring Relationship of Islamic Work Ethics and Organizational Behaviors among Engineering Students. Asia Proc. Soc. Sci. 2020, 6, 139-145. [CrossRef]

58. Murtaza, G.; Abbas, M.; Raja, U.; Roques, O.; Khalid, A.; Mushtaq, R. Impact of Islamic work ethics on organizational citizenship behaviors and knowledge-sharing behaviors. J. Bus. Ethics. 2016, 133, 325-333. [CrossRef]

59. Somers, M.J. Ethical Codes of Conduct and Organizational Context: A Study of the Relationship between Codes of Conduct, Employee Behavior and Organizational Values. J. Bus. Ethics 2001, 30, 185-195. [CrossRef]

60. Saunders, M.N.K.; Thornhill, A.; Lewis, P. Research Methods for Business Students, 5th ed.; Pearson: New York, NY, USA, 2009; p. 656.

61. Pillai, R.; Scandura, T.A.; Williams, E.A. Leadership and Organizational Justice: Similarities and Differences across Cultures. J. Int. Bus. Stud. 1999, 30, 763-779. [CrossRef]

62. Ali, A.J. Scaling an Islamic Work Ethic. J. Soc. Psychol. 1988, 128, 575-583. [CrossRef]

63. Hysenbegasi, A.; Hass, S.L.; Rowland, C.R. The impact of depression on the academic productivity of university students. J. Mental Health Policy Econ. 2005, 8, 145-151.

64. Gaultney, J.F. The prevalence of sleep disorders in college students: Impact on academic performance. J. Am. Coll. Health 2010, 59, 91-97. [CrossRef] [PubMed]

65. Hair, J.F.; Black, W.C.; Babin, B.J. Multivariate Data Analysis: A Global Perspective, 7th ed.; Pearson Education: Edinburgh, UK, 2010; p. 800 .

66. Kim, S.; Feldt, L.S. A Comparison of Tests for Equality of Two or More Independent Alpha Coefficients. J. Educ. Meas. 2008, 45, 179-193. [CrossRef]

67. Fornell, C.; Larcker, D.F. Evaluating Structural Equation Models with Unobservable Variables and Measurement Error. J. Mark. Res. 1981, 18, 39-50. [CrossRef]

68. Hayes, A.F. Introduction to Mediation, Moderation, and Conditional Process Analysis: A Regression-Based Approach; Guilford Publications: New York, NY, USA, 2017.

69. Hayes, A.F. Beyond Baron and Kenny: Statistical Mediation Analysis in the New Millennium. Commun. Monogr. 2009, 76, 408-420. [CrossRef]

70. Baron, R.M.; Kenny, D.A. The moderator-mediator variable distinction in social psychological research: Conceptual, strategic, and statistical considerations. J. Pers. Soc. Psychol. 1986, 51, 1173-1182. [CrossRef] [PubMed]

71. Preacher, K.J.; Hayes, A.F. SPSS and SAS procedures for estimating indirect effects in simple mediation models. Behav. Res. Methods Instrum. Comput. 2004, 36, 717-731. [CrossRef] [PubMed]

72. Ali, A.J. The Islamic work ethic in Arabia. J. Psychol. 1992, 126, 507-519. [CrossRef]

73. Rokhman, W. The Effect of Islamic Work Ethics on Work Outcomes. Electron. J. Bus. Ethics Organ. Stud. 2010, 15, $21-27$.

74. Ko, S.H.; Choi, Y.; Rhee, S.Y.; Moon, T.W. Social Capital and Organizational Citizenship Behavior: Double-Mediation of Emotional Regulation and Job Engagement. Sustainability 2018, 10, 3600. [CrossRef] 
75. Al Halbusi, H.; Estevez, J.P.; Eleen, T.; Ramayah, T.; Hossain Uzir, M.U. The Roles of The Physical Environment, Social Servicescape, Co-Created Value, and Customer Satisfaction in Determining Tourists' Citizenship Behavior: Malaysian Cultural and Creative Industries. Sustainability 2020, 12, 3229. [CrossRef]

76. Volchik, V.; Maslyukova, E. Performance and Sustainability of Higher Education: Key Indicators versus Academic Values; Social Science Research Network: Rochester, NY, USA, 2016.

77. Polo, Z.F.; Martín, S.J. Teaching for a Better World. Sustainability and Sustainable Development Goals in the Construction of a Change-Maker University. Sustainability 2019, 11, 4224. [CrossRef] 